\title{
UMBILICAL CORD BLOOD BANKING IN THE WORLDWIDE HEMATOPOIETIC STEM CELL TRANSPLANTATION SYSTEM: PERSPECTIVES FOR UKRAINE
}

\author{
T.O. Kalynychenko \\ State Institution "Institute of Hematology and Transfusiology of the National Academy of Medical \\ Sciences of Ukraine”, Kyiv 04060, Ukraine
}

\begin{abstract}
Significant progress in the promotion of procedural technologies associated with the transplantation of hematopoietic stem cells caused a rapid increase in activity. The exchange of hematopoietic stem cells for unrelated donor transplantations is now much easier due to the relevant international professional structures and organizations established to support cooperation and standard setting, as well as rules for the functioning of both national donor registries and cord blood banks. These processes are increasing every year and are contributing to the outpacing rates of development in this area. Products within their country should be regulated by the competent government authorities. This study analyzes the work of international and national levels of support for transplantation activity in the field of unrelated hematopoietic stem cell transplantation, the standardization order of technologies, as well as data that justify the need to create a network of donated umbilical cord blood banks in Ukraine as a factor in the development of allogeneic transplantation. This will promote the accessibility of international standards for the treatment of serious diseases for Ukrainian citizens.
\end{abstract}

Key Words: umbilical cord blood, hematopoietic stem cell, donor registries, allogeneic transplantation, cord blood bank.

\section{INTRODUCTION}

Hematopoietic cells are perhaps the only type of adult stem cells that has firmly become the part of the arsenal of medical care for life-threatening diseases.

Today, hematopoietic stem cell transplantation (HSCT) from bone marrow (BM), stimulated peripheral blood (PB), and umbilical cord blood (UCB) Is estimated as an effective way of curing for more than 80 serious diseases associated with hematopoietic system disorders. HSCT has gone through a half-century of development from experiment to the recognized successful medical technology [1-3].

In recent years, due to significant advances in procedural advancement technologies, the growth rate of the absolute quantitative indicators of HSCT has been steadily increasing, while the proportions of the

Submitted: July 30, 2017.

Correspondence: E-mail: kalynychenko_tetiana@ukr.net; kalynychenko.t@igt.net.ua

Abbreviations used: AABB - American Association of Blood Banks; AHCTA - Alliance for Harmonization of Cellular Therapy Accreditation; ASBMT - American Society for Blood and Marrow Transplantation; BM - bone marrow; BMDW - Bone Marrow Donors Worldwide; CBB - cord blood bank; CBMTG - Canadian Blood and Marrow Transplant Group; EBMT - European Group for Blood and Marrow Transplantation; FACT - Foundation for the ACcreditation of Cellular Therapy; HLA - human leukocyte antigen; HSC - hematopoietic stem cells; HSCT - hematopoietic stem cell transplantation; ISCT - International Society for Cellular Therapy; JACIE - Joint Accreditation Committee of ISCT-Europe and EBMT; NMDP - National Marrow Donor Program (US); PB - peripheral blood; PBSC - peripheral blood stem cells; SNTO - Spanish National Transplant Organization; UCB - umbilical cord blood; WBMT - Worldwide Network of Blood and Marrow Transplantation; WHO - World Health Organization; WMDA - World Marrow Donor Association; WMDA CBWG - The WMDA Cord Blood Working Group. using of donor types are constantly changing. According to The Worldwide Network of Blood and Marrow Transplantation (WBMT), the dominance of allogeneic variants over autologous transplants is the current trend of the global growth [4]. So, in comparison with 2006, the overall increase for 2012 was $46 \%$. At the same time, the number of the allogeneic transplants increased by $57 \%$, while the raise in the autologous transplantation was at the level of $38 \%$. A global analysis of the relative transplant activity indicators showed their heterogeneity with a significant advantage in favor of countries with a high gross domestic product per person, which is directly related to high expenditure volumes for health protection. In addition, the availability of an infrastructure in the form of a national hematopoietic stem cell (HSC) registries with a wide list of donors, large cord blood banks (CBBs), and transplant centers with professional cohesive teams is very important.

Unfortunately, these positive processes cover not all continents and regions. The widening gap in the indicators of transplant activity among countries with different economic development takes place, which, in its turn, raises the question of the need to strive for unification and price reducing medical technologies in this area.

\section{WORLD SUPPORTING EXPERIENCE IN THE FIELD OF UNRELATED HEMATOPOIETIC STEM CELL TRANSPLANT ACTIVITIES}

The guiding principles of the World Health Organization (WHO) declare the transplantation of organs, cells and tissues to be a global task, with the collection of activity data being one of the prime prerequisites [4-6].

Despite the rapid growth in the number of the transplantations, their rates for 10 million people in different regions of the world vary considerably (allogeneic transplants from 0.4 to 506$)[2,7]$. At what even 
in areas with a large number of transplantations, these numbers are far from oversaturation. For example, in the USA only a third of those patients who needed unrelated transplantation had a preliminary search for a donor in the National Marrow Donor Registry [7].

Thus, the question of how best to organize transplant activity is still open. A number of international non-governmental and non-profit organizations are engaged in scientific and practical issues in this field.

The WBMT, which has formal relations with WHO, has undertaken the mission of promoting best practices in HSCT area, as well as stem cell donation and cellular therapy. Its goal is to participate in scientific and educational activities and undertakings exclusively [8] .

At the national level, government agencies are engaged in the development of a transplant system. They take care of creating and supporting the operation of the infrastructure to ensure the healthcare activities for organ and tissue transplantation.

One of the most important components of such a country's infrastructure in the HSCT sphere is the national donor $\mathrm{HSC}$ registries that act as information databases and containing data on the voluntary donors (individual code, personal data, human leukocyte antigen (HLA) phenotype, information on their condition health at the time of entry into the registry database), and also include the data on the cryopreserved UCB units in the CBBs for unrelated transplantations.

A registry functions as a hub between different entities involved in the transplant process. The different entities connected to each other in different ways, depending on the country and the roles the registry chooses to take on [9].

One of the main voluntary organizations is The World Marrow Donor Association (WMDA). This is representative of blood stem cell donor registries, CBBs, other organizations and individuals with an interest in blood stem cell transplantation. According to its standards, the registry is "an organization responsible for coordinating of the search hematopoietic progenitor cells from donors (including cord blood) unrelated to the potential recipient".

At the urging of theWMDA, the HSC registries should be a resource of information on the regulatory rules of the countries in which they operate, as well as information on national and international partners [10]. Such registries have existed for more than 25 years. Today, most of them are united by The Bone Marrow Donors Worldwide (BMDW) as an international service [11]. The BMDW creates, provides, maintains and optimizes an electronic data bank with centralized data on HLA phenotypes and other relevant stem cell donor data from volunteers and cryopreserved UCB products and makes them available for search in the interests of the particular recipient, and does other related activities. Since January 2017 BMDW has become a service of the WMDA [11].

In turn, WMDA, which has been operating since 1994, has grown into a global association, representing donor registries, CBBs, donor centers, and transplant hospitals from 52 different countries [9]. Due to the fact that approximately $46 \%$ of HSC products cross borders, the goal of unrelated transplantation for the exchange cooperation between international registries is the WMDA mission $[10,12]$.

According to various sources, one in 1500 potential HSC donors becomes real. If the preliminary search yields about 10 thousand variants, then this is a good result for the prospect of obtaining the highest degree of compatibility. When restricting the list of 20 individuals, the search can be lengthy and ineffective. The high cost of searching and activating donors in the foreign registries makes the transplantation almost impossible for the ordinary citizens of the countries that are not in the global donor network.

Allowing to the WMDA standards [9], the cell collection center must be independent of the transplant center, both territorially and legally. The donor has the right to refuse a survey and donation at any stage without explaining the reason, which much slows down the selection and testing. In the early post-donation period, the donor remains under medical supervision of the cell collection center. His Registry carries out further medical care and monitoring of his health. As for related donors, the issues connected to their servicing have not been completely settled. A potential conflict of interest is the possible participation of the same team in the observation of both the donor and the recipient in the case of the related transplant [13]. Attention is paid to this issue in recent changes to international standards [14]. Other issues related to the standardization of donor health assessment, observation and medical and psychological assistance after donation, in accordance with the help of unrelated donors under existing procedures, as well as the transfer to centralized donor monitoring registries, are in a state of active discussion.

NetCord Foundation was founded in 1997 as a nonprofit organization and an international Eurocord arm for the purpose of promoting high-quality banking and clinical use of UCB for allogeneic HSCT through the online Virtual Office. This is a network of non-commercial public UCB banks in Europe, the United States, Israel, Japan, and Australia. It covered more than $50 \%$ of the world's non-commercial UCB banks, which have already provided more than 10 thousand transplants for adults and children. In 2007, The WMDA Cord Blood Working Group (WMDA CBWG) was established to collect and exchange information on cord blood registers and development of guidelines for international CBBs exchange for transplant safety [15]. According to the data of the WMDA CBWG, one of the difficulties during the decade was the duplication of lists in different services. So, until recently, the search in such systems as NetCord Virtual Office and the National Marrow Donor Program (NMDP) (US) Center for Cord Blood was interchangeable [15]. To date, since January 2017 this problem has been resolved by combining BMDW, WMDA and NetCord into a single organization. Since that time, according to the declaration, the NetCord working group will continue to work with the aim of supporting international exchange of cord blood units and harmonization of the world practice of bank storage [16]. 
Nowadays, UCB units can be quickly searched using a global computerized system that contains accredited banks from around the world. Search corresponds to WMDA guidelines.

Thus, today BMDW is the primary source of all HSC donors and cord blood units globally, and its holds over 30 million donors and over 700 thousand cord blood units from 98 registries and CBBs from 54 countries [11].

\section{HSC SOURCES FOR TRANSPLANTATION}

The use of BM as a HSC graft has more than 50 years of history $[17,18]$. During the period following the announcement of E. Donnall Thomas et al. (1975) about the first successes of such treatment of patients in the acute leukemia final stage, this source has been widely recognized as an effective immune and hematopoietic regenerator for serious diseases. Deficiency of donors, when it is necessary to maintain a high degree of histocompatibility of the donor-recipient pair, and also the invasiveness of the collection procedure, which is conducted under general anesthesia, stimulated an active search for new HSC sources. The procedure has complicating risks, including: the development of anemia, hypovolemia caused by large volumes of BM and blood extraction (in total up to 1500 liters depending on the weight of the donor), pain at the extraction site, bleeding, edema or nerve compression, perforation of the pelvic cavity or internal vessels, life-threatening cardiac or respiratory disorders, allergic reactions associated with general anesthesia $[10,19]$.

Another source - peripheral blood stem cells (PBSC), which today amounts to about $70 \%$ of all donations in unrelated conditions, also has a number of negative features associated primarily with the need to stimulate the ejection of stem cells into the PB. This is expressed in bone pain, nausea, vomiting, enlarged spleen, until it ruptures, insomnia, the appearance of flu-like symptoms, muscle pain. In addition, there is a danger of reactions at the venipuncture point, development of symptomatic citrate hypovolemia and hypocalcemia, and thrombocytopenia [10, 20-22]. Further research on the risks of development of early and late complications in PBSC donors continue, neoplastic processes including.

The general picture of the complications of donors confirms the need to apply strict criteria for the medical evaluation of candidates' suitability.

The UCB is an alternative to the adult donor hematopoietic tissue (BM or PBSC) for recipients who require transplantation in the absence of suitable donors.

The fact of HSC circulation in newborn PB was detected in the $80^{\text {th }}$ years of the twentieth century [23]. UCB early hematopoietic precursors have a number of ontogenetically determined characteristics, among which: increased proliferative potential relative to other adult hemopoietic tissue sources, as well as prolonged cell cycle, cellular signaling features, increased receptor sensitivity, ability to the autocrine growth factor producing [24].

Several first CBBs were established in the United States and Europe in the early 1990s [17]. After the first effective transplantation $[25,26]$, the number of such banks, as well as the using of stem cells from this source, has been increasing every year around the world [26-29]. Many studies have found that the frequency and degree of immune conflict in the graft-versus-host-disease form in case of UCB application are significantly lower than after BM transplantation [30-33]. In addition to the less stringent requirements for HLA compliance [34], the recipients of allogeneic UCB cells do not show an increased risk of the tumor relapse [28]. Presupposition for the formation of immunological tolerance is the neonatal nature of cells, including the absence of previous immunizations and activation of the lymphocytes by infectious agents. Increased (relative to the adult hematopoietic tissue donors) content of the non-activated immature lymphocytes, and the suppressor cells and a reduced monocyte amount with structures that determine their functional activity in intercellular immune responses (antigen-presenting structures, immune adhesion receptors, and others) are considered as features of the effector cells population composition. The disproportion of the mediator production, the sensitivity to them, and reduced cytotoxic reactivity are also signs of the functional immaturity of these immunocompetent cells $[35,36]$. A major advantage in the use of cord blood is the possibility of having a frozen unit in the transplant center before the start of the conditioning regimen for the recipient [15].

To date, they are successfully used in the treatment of hematological, oncologic and other diseases (acute and chronic leukemia, myelodysplastic syndrome, congenital anemia (Fanconi anemia), solid tumors, hemoglobinopathies, severe combined immunodeficiencies, congenital metabolic abnormalities, autoimmune diseases). The spectrum of diseases is constantly expanding [37-39]. But, according toWBMT data, about $70 \%$ of all cases of UCB use as the source of allogeneic transplantation were in patients with leukemia, 16\% - for non-cancerous diseases, $10 \%$ - for lymphoproliferative disorders, and only $1 \%$ - for solid tumors [4]. According to the NMDP (US) in 2010, 22\% of allogeneic unrelated transplantations were carried out due to the use of the UCB itself. At the same time in children's practice such transplantation is more effective than transplantation from the PBSC donors, therefore they were used more often [40]. Thus, the development of UCB transplantation is the reason for the rapid growth of allogeneic unrelated transplantation in many ways.

According to E. Gluckman data (2014), about 30 thousand UCB units distributed worldwide for adults and children with severe hematological diseases [26]. With increasing practice of performed UCB transplantation, the unit selection criteria become more perfect. This contributes to the globalization of cooperation [41].

\section{STANDARDIZATION IN THE FIELD RELATED TO THE UMBILICAL CORD BLOOD HEMOPOETIC STEM CELLS TRANSPLANTATION TECHNOLOGIES}

The need to develop international standards for collection, processing, testing, banking, selection and 
release implementation manifested itself against the backdrop of the UCB transplantation growing role and the international exchange of its samples. Such standards were established by NetCord in partnership with the Foundation for the Accreditation of Cellular Therapy (FACT). Leading organizations in the field of transplantation have adopted these rules since 2001. These include the European Group for Blood and Marrow Transplantation (EBMT), American Society for Blood and Marrow Transplantation (ASBMT), International Society for Cellular Therapy (ISCT), WMDA, Joint Accreditation Committee of ISCT-Europe and EBMT (JACIE), Spanish National Transplant Organization (SNTO), Canadian Blood and Marrow Transplant Group (CBMTG).

Compliance with these standards for quality assurance, validation and efficiency is the basis for inspection in a formal accreditation procedure, taking into account the rules of good manufacturing practices of the regulatory authorities of the country in which the cell bank is located.

At the same time, developments in the direction of the processing procedure improving, as well as the characteristics of the material, continue today, given the imperfection of the sample quality, even in the accredited banks. This is due to significant variability and low levels of the cell content, as well as the level of their viability indices.

The development of knowledge in this area leads to the fact that new editions of the Standards are published approximately every three years. This allows them to comply with the latest developments and the requirements of high-quality banking [42].

Today there is the Sixth Edition NetCord-Fact International Standards for Cord Blood Collection, Banking, and Release for Administration [43]. In addition, the current standards of The American Association of Blood Banks (AABB) form the basis of its accreditation program [16]. Alliance for Harmonization of CelIular Therapy Accreditation (AHCTA) with its members also promotes quality in the specified field [44].

Thus, the harmonization of standards and the promotion of high-quality UCB units at the international level is due to the accreditation programs offered by WMDA, Netcord Foundation in cooperation with FACT and the AABB, which are members of the AHCTA [15]. Each of these programs regulates various aspects of UCB unrelated transplantation - from issues related to UCB banking and its release to focusing on registry operations.

\section{SOME ISSUES OF PROVIDING UNRELATED TRANSPLANTS WITH UCB SAMPLES}

The provision of unrelated transplants with UCB HCS samples around the world is being done through nonprofit donor banks that are part of their international networks [15, 27, 29]. Most of the donor CBBs are in close connection with their national HSC registries. They enter international search systems through registration of the samples in a national database. The smaller part of banks are independent of the national registries, their databases either enter into international listings directly or operate locally only $[15,45]$. The transplant center receives extended information when sending a request for UCB samples to the system registry. The searching for the UCB unit provides fewer steps than for adult donor stem cells, because it is fully tested and all the necessary characteristics are provided already at the stage of including the unit in the search list. Due to the fact that the process does not require a clinical donor survey, in contrast to the processes in the collection of BM and PBSC, an emergency order can be performed in 1-2 days. Usually, it is 3-4 days after the notice. If additional viability tests or colony formation capacity are required, this period lasts up to 15 days [15].

There are no ethical or moral prejudices in connection with UCB banking. The units can be stored in the cryopreserved state for at least 20 years without harm to the viability of the cells [17]. The lack of a cell dose for the adult recipients is most likely a problem that is solved by conducting additional studies on double UCB transplantation. This method is especially popular in USA because of the cases of increased weight among the recipients. Also, the use of the reduced-intensity conditioning regimens for the transplantation in elderly patients reduces the request [17, 46, 47].

In fact, the financing and the targeted purpose for the use of banks they are divided into two categories: public and private. Public banks keep the UCB units for use in allogeneic unrelated transplantation programs and some limited types of research, while private banks focus on autologous or related applications. Family-directed banking can be useful for the families in whom an expected child has relatives who need the hematopoietic tissue transplant [48]. Some countries have public or private funding for storing the UCB units specifically for the families in which there is such a need, called "hybrid banking" [49, 50]. At the same time, the functioning of the public and private banks raises ethical and legal issues. The inadmissibility of the commercialization of the human body, control and equitable access to medical services are among the main problems [51-55]. Unconditional priority of altruistic donation of the UCB for interests of society over autologous private storage should be combined with detailed, accurate and timely information for the parents that takes into account all the pros and cons of these types of banking. Family members should receive detailed information about the therapeutic potential of the material and the realistic expectations of its use. It is necessary to realize that the expansion of private banks is a significant problem for the functioning of public volunteer banks, and, conversely, a generous gift in the form of donation can save the life of a needy person and does not have negative consequences for the donor $[48,56]$.

\section{A LOOK AT THE ADVANTAGES AND PROSPECTS OF UCB BANKING IN THE CONTEXT OF THE HSC TRANSPLANT SYSTEM OF UKRAINE}

According to the WHO definition, transplantation is an important global task. Such treatment should be perceived as a generally accessible "standard 
of care", not limited to the affluent countries or individuals $[1,5]$. In this regard, the WHO guiding principles declare: the transplant regulation on a national level is a governmental responsibility. Considering that Ukraine has been a permanent member of WHO since 1948, the principles and international legal recommendations of this organization are binding for our country both at the legislative level and in the practical implementation plane.

In the opinion of Dr Luc Noël in charge of transplantation atWHO and a bioethics consultant atWHO Dr Dominique Martin: "The pursuit of national self-sufficiency in human material for transplantation is the collective responsibility of all citizens, inasmuch as they are necessary participants in the prevention and management of all diseases leading to the need for transplantation" [57].

It should be emphasized that HSCT is a vivid example of costly specialized medical care. In this regard, its widespread use was limited to high-income countries until recently. However, recently the situation has changed somewhat $[1,58]$. The number of transplantations has increased worldwide, including through the use of an alternative donor material: HLA-matched unrelated donors and HLA-matched UCB cells, as well as increased use of mobilized stem hemopoietic cells of the PB [59]. In addition, such changes are due to the spread of transplantation technologies with the use of the allografts for elderly recipients against the background of successful clinical trials in such direction as conditioning with reduced intensity mode, as well as the use of either double HLA-mismatched UCB grafts or related HLA-haploidentical BM material [60-62].

Unfortunately, in Ukraine, with the existence of transplant centers with highly qualified teams, the introduction of unrelated transplantations to those patients who do not have an HLA-compatible donor-relative remains the biggest problem. Today, the high cost of searching for and activating donors in foreign registries for countries such as Ukraine that are not members of the WMDA makes transplantation inaccessible for most Ukrainian patients. In addition, the problem is the lack of a distinct legal regulation in this area.

According to economic and social indicators, profitable and realistic in the conditions of Ukraine through the creation of HSCT reserves is the introduction of the donor CBBs system for public use, with their state ownership. The reason for this conclusion, among other things, is the fact that this material is usually subject to disposal after childbirth along with the whole fetoplacental complex. The state's responsibility is to ensure the operation of such banks, to promote high unified quality of the product through international accreditation and standardization, with the guarantee of the entry of the national banks into international search systems through membership in the association of non-profit UCB banks. Alternatively, the introduction of a transitional model of hybrid banking on the basis of family banks, which already exist today in the field of private medicine in Ukraine, can serve as a matter for discussion. Storage of UCB units for allogeneic transplantation in such banks is possible only when international standardization of samples is per- formed. After restoring economic indicators, a model of a state bank with partial preservation of samples for family use would be useful for Ukraine, provided that they are available to patients who are not related to the donor family. Such banks today have priority in some states [48, $56,63]$. Therefore, the creation of a network of donor CBBs in Ukraine is quite feasible, taking into account the experience and development of specialized research institutes of our country in this direction.

Practice shows that a thorough analysis of the experience of transplantation failures and successes promotes progress in this area of activity [2]. There are all prerequisites of historical, professional and economic nature for the development of the transplantation system of hematopoietic tissue in Ukraine. Thus, the scientific literature of the 70-80s of the 20th century covers the history of transplantation in our country [64-66]. These data, most likely, unfortunately, were not taken into account in a global analysis of all transplantation activities conducted recently for the WBMT [2]. In addition, Ukraine has strong scientific traditions and schools in the field of cryopreservation of hemopoietic tissue, including the experience of creation and functioning of cryobanks [67, 68]. Preconditions of an economic nature allow us to hope for Ukraine's exit from the cohort of countries with low macroeconomic indicators. Although the gross national income per person in Ukraine still remains very low due to various reasons and accounts for only $20 \%$ of the average for the EU, the economy shows the desired signs of recovery [69]. The cost of providing samples at the national level and the proper degree of self-sufficiency in this sense requires careful calculations, but it is already clear that the cost price of such a sample for the Ukrainian consumer will be significantly lower compared to the international exchange of samples originating from countries with highly developed economies. Although it should be borne in mind that the inclusion of the bank in the international exchange of samples contributes to their economic profitability [70]. In general, the lowtemperature banks of donor UCB hematopoietic tissue are a real chance of obtaining a non-related graft, primarily for use in a hematology clinic.

\section{CONCLUSION}

Thus, the problem of providing transplant centers with sufficient and suitable stocks for clinical use is being solved by creating a register of prospective donors of the BM or PBSC, as well as the UCB cryobanks. Given the financial feasibility, the existing advantages of the cord blood over other sources of HSC, a network of donor cryobanks with state ownership and a national registry of HLA-type units is necessary for the establishment in Ukraine. Creation of hybrid models of banks, including both samples for private storage, and units donated for public needs, is a problem for discussion. Bank regulation should be carried out based on public information discussion within attracting a wide range of specialists with giving priority to the public interest. This will contribute, first, to the correct national regulation of activities in this area, and 
second, to the process of international accreditation. In general, the introduction of the method into clinical practice depends entirely on the state care and financing of the program for hemopoietic cell transplantation.

\section{REFERENCES}

1. Gratwohl A, Baldomero $\mathrm{H}$, Gratwohl $\mathrm{M}$, et al. Worldwide Network of Blood and Marrow Transplantation (WBMT). Quantitative and qualitative differences in use and trends of hematopoietic stem cell transplantation: a Global Observational Study. Haematologica 2013; 98: 1282-90.

2. Gratwohl A, Pasquini MC, Aljurf M, et al. One million haemopoietic stem-cell transplants: a retrospective observational study. Lancet Haematol 2015; 2: e91-100.

3. Health Resources and Services Administration: U.S. Department of Health and Human Services. Available at https://bloodcell.transplant.hrsa.gov/research. Accessed July 18, 2017.

4. Niederwieser D, Baldomero H, Szer J, et al. Worldwide Network of Blood and Marrow Transplantation (WBMT) Hematopoietic stem cell transplantation activity worldwide in 2012 and a SWOT analysis of the Worldwide Network for Blood and Marrow Transplantation Group including the global survey. Bone Marrow Transplant 2016; 51: 778-85.

5. World Health Organization. WHO guiding principles on human cell, tissue and organ transplantation. Transplantation 2010; 90: 229-33.

6. White SL, Hirth R, Mahíllo B, et al. The global diffusion of organ transplantation: trends, drivers and policy implications. Bull World Health Organ 2014; 92: 826-35.

7. Copelan E. HSCT: navigating the journey ahead. Lancet Haematol 2015; 2: e83-4.

8. Worldwide Network for Blood and Marrow Transplantation. Available at http://www.wbmt.org. Accessed July 18, 2017.

9. World Marrow Donor Association. Available at https://www.wmda.info/professionals. Accessed July 18, 2017.

10. Lown RN, Philippe J, Navarro W, et al. Unrelated adult stem cell donor medical suitability: recommendations from the World Marrow Donor Association Clinical Working Group Committee. Bone Marrow Transplant 2014; 49: 880-6.

11. Bone Marrow Donors Worldwide. Available at https://www.bmdw.org/bmdw/about-bmdw. Accessed July 14, 2017.

12. Petersdorf EW. The World Marrow Donor Association: 20 years of international collaboration for the support of unrelated donor and cord blood hematopoietic cell transplantation. Bone Marrow Transplant 2010; 45: 807-10.

13. Anthias C, van Walraven SM, Sørensen BS, et al. Related hematopoietic cell donor care: is there a role for unrelated donor registries? Bone Marrow Transplant 2015; 50: 637-41.

14. Joint Accreditation Committee-ISCT \& EBMT. International standards for cellular therapy product collection processing and adminstration. $5^{\text {th }}$ edition. Available at http:// www.jacie.org. Accessed July 20, 2017.

15. Welte K, Foeken L, Gluckman E, Navarrete C. International exchange of cord blood units: the registry aspects. Bone Marrow Transplantation 2010; 45: 825-31.

16. NetCord. Available at http://www.netcord.org. Accessed July 20, 2017.

17. Ballen KK, Gluckman E, Broxmeyer HE. Umbilical cord blood transplantation: the first 25 years and beyond. Blood 2013; 122: 491-8.

18. Appelbaum FR. Hematopoietic cell transplantation at 50. N Engl J Med 2007; 357: 1472-5.
19. Lown RN, Shaw BE. 'First do no harm': where do we stand on unrelated hematopoietic cell donor safety? Expert Rev Hematol 2012; 5: 249-52.

20. Tulpule S, Shaw BE, Makoni P, et al. Severe allergic reaction with anaphylaxis to G-CSF (lenograstim) in a healthy donor. Bone Marrow Transplant 2009; 44: 129-30.

21. Holig K, Kramer M, Kroschinsky F, et al. Safety and efficacy of hematopoietic stem cell collection from mobilized peripheral blood in unrelated volunteers: 12 years of singlecenter experience in 3928 donors. Blood 2009; 114: 3757-63.

22. Nagler A, Korenstein-Ilan A, Amiel A, Avivi L. Granulocyte colony-stimulating factor generates epigenetic and genetic alterations in lymphocytes of normal volunteer donors of stem cells. Exp Hematol 2004; 32: 122-30.

23. Broxmeyer HE, Douglas GW, Hangoc G, et al. Human umbilical cord blood as a potential source of transplantable hematopoietic stem/progenitor cells. Proc Natl Acad Sci USA 1989 ; 86: $3828-32$

24. Broxmeyer HE. Insights into the biology of cord blood stem/progenitor cells. Cell Prolif 2011; 44: 55-9.

25. Gluckman $\mathrm{E}$, Broxmeyer $\mathrm{HA}$, Auerbach $\mathrm{AD}$, et al. Hematopoietic reconstitution in a patient with Fanconi's anemia by means of umbilical cord blood from an HLA-identical sibling. N Engl J Med 1989; 321: 1174-8.

26. Gluckman E. Foreword. In: Stavropoulos-Giokas C, Charron D, Navarrete C, eds. Cord Blood Stem Cells Medicine. Academic Press. Elsevier Inc, 2015: xvii.

27. Katz G. Cord blood banking in France: Reorganizing the national network. Transfusion and Apheresis Science 2010; 42: 307-16.

28. Rocha V, Cornish J, Sievers EL, et al. Comparison of outcomes of unrelated bone marrow and umbilical cord blood transplants in children with acute leukemia. Blood 2001; 97: 2962-71.

29. Petrini C. European regulations on cord blood banking: an overview. Transfusion 2012; 52: 668-79.

30. Wagner JE, Gluckman E. Umbilical cord blood transplantation: the first 20 years. Semin Hematol 2010; 47: 3-12.

31. Gluckman E, Rocha V, Boyer-Chammard A, et al. Eurocord Transplant Group and the European Blood and Marrow Transplantation Group. Outcome of cord-blood transplantation from related and unrelated donors. N Engl J Med 1997; 337: $373-81$.

32. Gluckman E, Ruggeri A, Volt F, et al. Milestones in umbilical cord blood transplantation. Br J Haematol 2011; 154: $441-7$.

33. Rubinstein $P$, Carrier $C$, Scaradavou A, et al. Outcomes among 562 recipients of placental-blood transplants from unrelated donors. N Engl J Med 1998; 339: 1565-77.

34. Caillat-Zucman $S$, Le Deist F, Haddad E, et al. Impact of HLA matching on outcome of hematopoietic stem cell transplantation in children with inherited diseases: a single-center comparative analysis of genoidentical, haploidentical or unrelated donors. Bone Marrow Transplant 2004; 33: 1089-95.

35. Harris DT, Schumacher MJ, Locascio J, et al. Phenotypic and functional immaturity of human umbilical cord blood T lymphocytes. Proc Natl Acad Sci USA 1992; 89: $10006-10$.

36. Goltsev AN, Kalinichenko TA. Human umbilical cord blood as a sourse of hemopoietic cells for clinical application. Part II. Nature of hemopoietic potential. Probl Cryobiol 1998; 3: 3-21.

37. Barker JN. How I treat: the selection and acquisition of unrelated cord blood grafts. Blood 2011; 117: 2332-9.

38. Prasad VK, Mendizabal A, Parikh SH, et al. Unrelated donor umbilical cord blood transplantation for inherited meta- 
bolic disorders in 159 pediatric patients from a single center: influence of cellular composition of the graft on transplantation outcomes. Blood 2008; 112: 2979-89.

39. Takagi S, Ota Y, Uchida N, et al. Successful engraftment after reduced-intensity umbilical cord blood transplantation for myelofibrosis. Blood 2010; 116: 649-52.

40. Kurtzberg J, Prasad VK, Carter SL, et al. Results of the Cord Blood Transplantation Study (COBLT): clinical outcomes of unrelated donor umbilical cord blood transplantation in pediatric patients with hematologic malignancies. Blood 2008; 112: 4318-27.

41. Danby R, Rocha V. Clinical use of umbilical cord blood cells. In: Cord blood stem cells medicine. StavropoulosGiokas C, Charron D, Navarrete C, eds. Academic Press, 2015: 77-97.

42. International NetCord Foundation. Available at http://www.arthiqs.eu/partners/collaborators/international-netcord-foundation. Accessed July 18, 2017.

43. Sixth Edition NetCord-FACT International Standards for Cord Blood Collection, Banking, and Release for Administration (free download). Available at http://www.factweb.org/forms/store/ProductFormPublic. Accessed July 18, 2017.

44. Alliance for Harmonisation of Cellular Therapy Accreditation. Available at http://www.ahcta.org/about.html. Accessed July 20, 2017.

45. Allan D, Petraszko T, Elmoazzen H, Smith S. Review of factors influencing the banking of collected umbilical cord blood units. Stem Cells Int 2013; Article ID 463031.

46. Ballen KK, Spitzer TR, Yeap BY, et al. Double unrelated reduced-intensity umbilical cord blood transplantation in adults. Biol Blood Marrow Transplant 2007; 13: 82-9.

47. Brunstein CG, Gutman JA, Weisdorf DJ, et al. Allogeneic hematopoetic cell transplantation for hematologic malignancy: Relative risks and benefits of double umbilical cord blood. Blood 2010; 116: 4693-9.

48. Gluckman E, Ruggeri A, Rocha V, et al. Familydirected umbilical cord blood banking. Haematologica 2011; 96: $1700-7$.

49. Armson BA, Allan DS, Casper RF. Umbilical cord blood: counselling, collection, and banking. J Obstet Gynaecol Can 2015; 37: 832-44.

50. Screnci M, Murgi E, Valle V, et al. Sibling cord blood donor program for hematopoietic cell transplantation: the 20year experience in the Rome Cord Blood Bank. Blood Cells Mol Dis 2016; 57: 71-3.

51. Fisk NM, Atun R. Public-private partnership in cord blood banking. BMJ 2008; 336: 642-4.

52. Mohr A, Busby H, Hervey T, Dingwall R. Mapping the role of official bioethics advice in the governance of biotechnologies in the EU: the European Group on Ethics' Opinion on commercial cord blood banking'. Science Public Policy 2012; 39: 105-17.

53. Petrini C. A comparative analysis of the opinions from European national and international ethics committees regarding the collection, storage and use of umbilical cord blood. Blood Transfusion 2012; 10: 279-89.

54. Petrini C. Ethical issues in umbilical cord blood banking: a comparative analysis of documents from national and international institutions. Transfusion 2013; 53: 902-10.

55. Parco S, Vascotto F, Visconti P. Public banking of umbilical cord blood or storage in a private bank: testing social and ethical policy in northeastern Italy. J Blood Med 2013; 4: 23-9.

56. Petrini C. Umbilical cord blood collection, storage and use: ethical issues. Blood Transfusion 2010; 8: 139-48.
57. Noël L, Martin D. Progress towards national selfsufficiency in organ transplants Bull World Health Organ 2009; 87: 647. http://dx.doi.org/10.1590/S0042-96862009000900003. Accessed 17 July 2017.

58. Pasquini M, Wang Z, Horowitz MM, Gale RP. 2013 report from the Center for International Blood and Marrow Transplant Research (CIBMTR): current uses and outcomes of hematopoietic cell transplants for blood and bone marrow disorders. Clin Transpl 2013: 187-97.

59. Holtick U, Albrecht M, Chemnitz JM, et al. Bone marrow versus peripheral blood allogeneic haematopoietic stem cell transplantation for haematological malignancies in adults. Cochrane Database Syst Rev 2014; 20: CD010189. doi: 10.1002/14651858.CD010189.pub2.

60. Sorror ML, Sandmaier BM, Storer BE, et al. Longterm outcomes among older patients following nonmyeloablative conditioning and allogeneic hematopoietic cell transplantation for advanced hematologic malignancies. JAMA 2011; 306: 1874-83.

61. Weisdorf D, Eapen M, Ruggeri A, et al. Alternative donor transplantation for older patients with acute myeloid leukemia in first complete remission: a center for international blood and marrow transplant research-eurocord analysis. Biol Blood Marrow Transplant 2014; 20: 816-22.

62. Eapen M, O'Donnell P, Brunstein CG, et al. Mismatched related and unrelated donors for allogeneic hematopoietic cell transplantation for adults with hematologic malignancies. Biol Blood Marrow Transplant 2014; 20: $1485-92$.

63. Aznar Lucea J. Umbilical cord blood banks. Ethical aspects. Public versus private banks. Cuad Bioet 2012; 23: $269-85$.

64. Lavrik S. Transplantation of cryopreserved bone marrow in experiment and clinic. In: Lavrik S, ed. Cryopreservation of bone marrow. Kyiv: Health, 1975: 87-95 (in Russian).

65. Romanova AF. Allogeneic bone marrow transplantation in complex treatment of patients with hypo- and aplastic anemia. In: Romanova AF, ed. Hypoplastic and aplastic anemia. Kyiv: Health, 1982: 78-122 (in Russian).

66. Kindzelsky LP, Zverkova AS, Sivkovich SA, et al. Chapter 3. Features of treatment of victims due to the Chernobyl disaster. 3.3. Transfusion of bone marrow in the treatment of cytotoxic disease. In: Kindzelsky LP, et al., eds. Acute radiation sickness in the conditions of the Chernobyl disaster. Kyiv: Teleoptik, 2002: 188-99 (in Russian).

67. Perekhrestenko PM, Kalynychenko TO, Glukhenka GT, Algazinova MK. Creation of the hematopoietic cell cryopreservation laboratory in Kiev: historical background. In: Materials of the scientific-practical conference with the participation of international specialists devoted to the $75^{\text {th }}$ anniversary of the State Institution "Institute of Hematology and Transfusion of the National Academy of Medical Sciences of Ukraine". Kyiv: Atika-N, 2011: 176-78 (in Ukrainian).

68. Goltsev AN. Institute for problems of cryobiology and cryomedicine of the National Academy of Sciences of Ukraine: history, present, future. Probl Cryobiol 2012; 22: 233 (in Russian and in English).

69. Gross national income of Ukraine in 2016 - UAH 2.358 trillion. Available at http://zik.ua/news/2017/04/24/ valovyy_natsionalnyy_dohid_ukrainy_u_2016_rotsi_2358 trln_gryven_1085217. Accessed 18 July 2017.

70. Brown N, Machin L, McLeod D. Immunitary bioeconomy: the economisation of life in the international cord blood market. Soc Sci Med 2011; 72: 1115-22. 